УДК 377:172:745:14

DOI:

Поліна Прохорчук, аспірант, молодший науковий співробітник Інституту професійно-технічної освіти НАПН Украӥни

\title{
КРИТЕРІЇ, КОМПОНЕНТИ, ПОКАЗНИКИ ТА РІВНІ ФОРМУВАННЯ ПРОФЕСІЙНО-ЕТИЧНОӤ КУЛЬТУРИ МАЙБУТНІХ ГРАФІЧНИХ ДИЗАЙНЕРІВ
}

Стаття присвячена проблемі формування професійно-етичної культури графічного дизайнера. Проблема вимірювання рівня формування професійно-етичної культури майбутніх графічних дизайнерів пов'язана з вибором критеріїв, їх показників та рівнів сформованості. У статті розглянуті критерії, компоненти, показники та рівні формування професійно-етичної культури графічних дизайнерів. Визначені рівні формування професійно-етичної культури графічних дизайнерів: адаптивний (низький), репродуктивний (середній), творчій (високий).

Ключові слова: структура професійно-етичної культури; професійно-етична культура; графічні дизайнери; критерії, компоненти та рівні професійно-етичної культури графічних дизайнерів; діяльнісний критерій; інформаційно-знаннєвий критерій; особистісно-креативний; мотиваційно-ціннісний критерій.

Puc. 1. Лim. 6.

Polina Prokhorchuk, Postgraduate Student, Junior Researcher at the Institute of Professional and Technical Education of the National Academy of Sciences of Ukraine

\section{CRITERIA, COMPONENTS, INDICATORS AND LEVELS OF FORMATION OF PROFESSIONALAND ETHICAL CULTURE OF FUTURE GRAPHIC DESIGNERS}

Modern technologies development directly influences the change and formation of new professional requirements, norms, and rules for the specialist of a particular profession. The formation's problem of professional and graphic designer's ethical culture needs special attention, because the specifics of the profession associated with graphic design - a specific area of visual communication, which direct contact and affects society.

The purpose of the publication is to highlight the structure of the formation of professional and ethical culture in future graphic designers. To determine the best ways to prepare future graphic designers, the actual problem is determining the structure of professional and ethical culture of the future graphic designers.

In the article the structure of formation of professional and ethical culture of future graphic designers is considered. The problem of measuring the level of formation of professional and ethical culture of the future graphic designers connected with the choice of criteria and indicators of their level of development. Analysis of modern scientific educational research in the field of education, formation and development of professional culture, ethical (moral) culture, professional and ethical culture and expert assessment criteria of importance given the right to select the following criteria for the formation of professional and ethical culture of graphic designers at colleges, active, motivational-value, personal-creative and informational-knowledge criteria. The formation levels of professional and ethical culture graphic designers: adaptive (low), reproduction (intermediate), creative (high).

Our research results are developing the structure and levels of the formation of the professional and ethical culture of future graphic designers. The directions of further research determine the pedagogical conditions for formation of professional and ethical culture of future graphic designers.

Keywords: a structure of professional and ethical culture; professional and ethical culture; graphic designers; criteria; components and levels of professional and ethical culture of graphic designers; an activity; informationknowledge; personality-creative; motivational-value criteria.

П остановка проблеми. Сучасна наукова громадськість розуміє під культурою - рівень освіченості, вихованості людей, а також рівень володіння якоюсь галуззю знань або діяльністю. Діяльність культури спрямована на вдосконалення оточуючої дійсності за рахунок внутрішнього багатства особистості. Основні риси людини, як особистості і особистість фахівця формується в процесі здобуття професійної освіти, розвиваються в процесі виконання конкретних завдань.

3 розвитком сучасних технологій змінюється і формуються нові професійні вимоги, норми, правила до фахівця конкретної професії. Сучасна професійна освіта спрямована не лише на підготовку конкурентоспроможного фахівця, який спроможний до творчої діяльності на професійних теренах, але й фахівця з чіткою системою цінностей. Під професійною культурою розуміють - знання, уміння, навички, і певні особисті якості, норми конкретної професійної діяльності. Складовою професійної культури $є$ професійноетична культура, яка відповідає за моральні принципи, норми, правила поведінки фахівця. 
Особливої уваги вимагає проблема формування професійно-етичної культури графічного дизайнера, адже специфіка цієї професії пов'язана з графічним дизайном - як специфічною візуальнокомунікаційною сферою, що безпосередньо контактує і впливає на соціум.

Саме тому, зважаючи на все вищесказане, для визначення оптимальних способів підготовки майбутніх графічних дизайнерів, актуальною $є$ проблема визначення структури професійноетичної культури майбутніх графічних дизайнерів.

Аналіз останніх джерел і публікацій. У сучасній педагогічній науці існують різні погляди щодо структури “професійної культури". Однак визначення структури “професійно-етична культура графічних дизайнерів у коледжах” у науковій літературі не зустрічається. Усі дослідження, присвячені даній проблематиці умовно можна поділити на три групи.

Перша група робіт стосується професійної культури. Вивченню професійної культури присвячені роботи М.О. Пічкура, С.В. Щабельник, Н.С. Сидоренка, М.І. Міхнюк, О.Л. Тульської, I. Ісаєв.

Друга група розкриває етичну або моральну культуру: О.І. Денищик, А.А. Каленський, С.А. Гаряча, О.Н. Олегівна, Л.Ю. Москальова, В.В. Салко.

Третя група робіт спрямована на вивчення професійно-етичної культури: О.В. Пон а м о ре н ко, А.О. Агаркова, Ю.І. КолісникГуменюк, И.В. Танвель, А.В. Симзяєв, О.В. Павлова.

Постановка завдання (цілей статті). Метою статті $\epsilon$ обгрунтування системи критеріїв, показників, компонентів та рівнів формування професійноетичної культури майбутніх графічних дизайнерів.

\section{Виклад основного} матеріалу дослідження. У процесі дослідження для обгрунтування системи компонентів, критеріїв та показників нами був застосований комплекс теоретичних і емпіричних методів. Використано такі теоретичні методи, як аналіз монографій, дисертаційних досліджень, статей, матеріалів науково-практичних конференцій, психологопедагогічної, методичної, спеціальної літератури 3 проблеми дослідження.

3 емпіричних методів застосовувалося інтерв'ю, бесіди з викладачами, студентами, фахівцями в галузі і метод експертного оцінювання. Дослідження виконувалося в Інституті професійно-технічної освіти навчання НАПН України відповідно до теми науково-дослідної роботи "Методичні основи стандартизації професійної освіти молодших спеціалістів у коледжах і технікумах".

Для розкриття структури професійно-етичної культури необхідно нагадати визначення суті предмету дослідження. Отже, "Професійноетична культура графічного дизайнера", - це сукупність моральних цінностей та етичних норм, які стали внутрішніми особистісними переконаннями і спрямовують професійну діяльність графічних дизайнерів на формування морально-етичної культури суспільства. Вона наповнює професійним змістом процеси діяльності й посилює загальнокультурну спрямованість, відображаючи досягнутий у ній рівень майстерності й формуючи відповідальне ставлення до кінцевого продукту праці графічного дизайнера [3, 197].

3 визначення суті предмету дослідження, аналізу науково-педагогічної літератури літератури, професіограми графічного дизайнера випливає структура професійно-етичної культури майбутніх графічних дизайнерів (рис. 1).

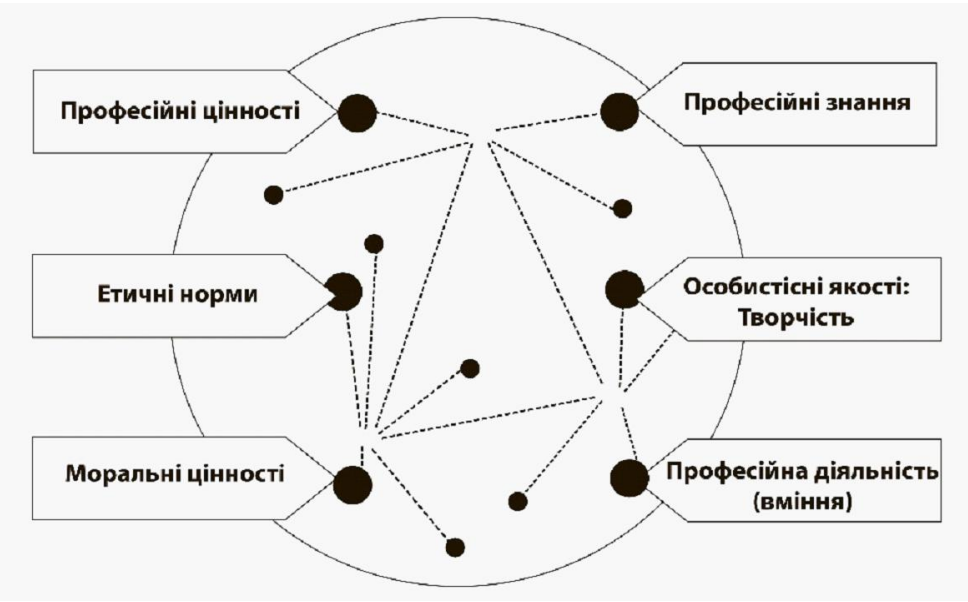

Рис. 1. Структура професійно-етичної культури майбутніх графічних дизайнерів

Проблема вимірювання рівня формування професійно-етичної культури майбутніх графічних дизайнерів пов'язана 3 вибором критеріїв, їх показників та рівнів сформованості. Поняття “критерій” С. Гончаренко розглядав “як засіб, оцінку, мірило чогось” [5, 81$]$.

Критерії професійної культури, на думку I. Ісаєва, мають визначатися 3 урахуванням системного розуміння культури, іiі структурних $\mathrm{i}$ функціональних складових, результату творчого 
засвоєння і створення педагогічних цінностей, професійно-творчої самореалізації особистості викладача $[1,115]$.

Для обгрунтування критеріїв, компонентів та показників нами, окрім аналізу напрацювань інших науковців і дослідників, також було враховано думки 20 експертів (викладачі зі стажем фахової та педагогічної діяльності не менше 10 років у коледжах і технікумах дизайн напряму), які висловлювали своє ставлення щодо основних критеріїв оцінювання сформованості професійноетичної культури майбутніх графічних дизайнерів, а також власні узагальнення про те, що ці критерії мають міжпредметний характер, відображають високу інформаційну і технологічну насиченість їх діяльності, а саме: діяльнісний критерій (діяльнісно-організаційний компонент), мотиваційноціннісний критерій (аксіологічний компонент), особистісно-креативний критерій (особистіснотворчій компонент) та інформаційно-знаннєвий критерій (інформаційно-когнітивний компонент).

Розглянемо детальніше кожен 3 компонентів та критеріїв формування професійно-етичної культури майбутніх графічних дизайнерів.

Діяльнісно-організаційний компонент, який включає готовність послуговуватися професійноетичними знаннями та цінностями у професійній діяльності, уміння використовувати знання і досвід для вирішення поставлених завдань, передбачати наслідки взаємодії власного графічного продукту 3 соціумом, здатність створювати графічний продукт, який відповідає етичним та естетичним нормам, що не суперечать етичному кодексу графічного дизайнера, діяти морально в складних професійних ситуаціях.

Показниками діяльнісного критерію визначено: уміння застосовувати етичні знання для вирішення завдань для вирішення завдань навчально-виховного процесу; уміння діагностувати композицію на вміст елементів, візуальних образів, які не відповідають загальнолюдським моральним цінностям, нормам, ідеалам, традиціям тощо; якості: професійно-етичні цінності стають складовою професійної діяльності; здатність передбачати наслідки впливу дизайн-продукту на кінцеву аудиторію і нести за це відповідальність [2, 252].

Аксіологічний компонент є стрижнем в системі формування професійно-етичної культури графічних дизайнерів у коледжах, оскільки головним завданням професійно-етичної культури $\epsilon$ формування ціннісної свідомості, ціннісного ставлення, ціннісної професійної діяльності особистості. Цей компонент характеризує позитивне ставлення до базових етичних цінностей, цінностей етичного кодексуграфічного дизайнера, цінностей етнічної культури.

Таким чином мотиваційно-ціннісний критерій може бути представлений такими показниками: знання про систему загальнолюдських моральних цінностей, норм, ідеалів традицій конкретного етносу, нації на яку розрахована інфографіка, візуальні образи, тощо; інтерес до майбутньої професійної діяльності та бажання їі здійснювати; сформованість цінностей професійної діяльності [3,87].

Інформаційно-когнітивний компонент визначено як освіченість, що включає низку засвоєних професійно-етичних, професійнодизайнерських знань, загальнолюдських моральних цінностей, норм, ідеалів, традицій способів пізнання навколишнього світу, соціальних практик, зафіксованих в текстах, здатність до пошуку та аналізу професійної літератури, що припускає наявність таких показників: професійні знання: знання основ композиції та кольорознавства; здатність оперувати професійними дизайн-програмами для ПК; професійно-етичні знання: здатність регулювати свою власну інформаційну поведінку на основі морально-етичних цінностей.

Особистісно-творчій компонент забезпечуе успішність творчого зростання графічного дизайнера $i$ сприяє його самореалізації $i$ реалізується на основі особистісно-креативного критерія, показниками якого є новаторство, творчий потенціал, професійна інтуїція; творче виконання завдань, проектів, індивідуальзоване сприйняття предметів і явищ світу; готовність до сприйняття нового, невизначеного, незвичного; пошук глибинного змісту візуального образу.

Розглянуті критерії та показники перебували в тісному взаємозв' язку і слугують орієнтирами, що дозволили охарактеризувати рівні формування професійно-етичної культури графічних дизайнерів у коледжах.

Наприклад, М. Ситникова розглядає наступні рівні культури професійно-педагогічної самореалізації: адаптивний, продуктивний, творчий $[4,25]$.

Урахування визначених критеріїв і показників дало змогу виокремити чотири рівні сформованості професійно-етичної культури графічних дизайнерів: адаптивний (низький), репродуктивний (середній), творчий(високий).

Для адаптивного (низького) рівня професійноетичної культури майбутніх графічних дизайнерів характерні фрагментарні знання про сутність і зміст професійно-етичної культури. Таким студентам бракує стійкості у моральному виборі, 


\section{КРИТЕРІЇ, КОМПОНЕНТИ, ПОКАЗНИКИ ТАРІВНІ ФОРМУВАННЯПРОФЕСІЙНО-ЕТИЧНОӤ КУЛЬТУРИ МАЙБУТНІХГРАФІЧНИХ ДИЗАЙНЕРІВ}

властива однобічність суджень про моральноетичні норми, формалізм у рішенні ситуацій морально-етичного характеру. Студенти, які належать до цієї групи, визнають важливість професійно-етичної культури у професійній діяльності, але не виявляють зацікавленості до їі аналізу. Здатність до аналізу, графічних зображень проявляється, але тільки у граничних випадках, більшість 3 таких студентів не виявляють щирого бажання до вивчення етичного кодексу графічного дизайнера, генерації нових ідей у дизайн проектах. У них недостатньо сформовані вміння діагностувати і планувати завдання;. Такі студенти не вміють генерувати креативні ідеї та втілювати їх під час професійної практики.

Для репродуктивного (середнього) рівня професійно-етичної культури графічного дизайнера характеризується епізодичним проявом взаємозв'язку моральної свідомості, почуттів, діяльності; неповною поінформованістю та фрагментарністю знань про зміст професійноетичної культури, іiі фундамент. Студенти даного рівня розрізняють категорії “добро” і “зло”, але не завжди вміють оцінювати події та явища 3 моральних позицій. Усвідомлення значення морально-етичних понять, цінностей дизайнераграфіка характеризується ситуативністю, але в цілому їхній моральний вибір позитивний, як і ставлення до цінностей дизайн професії; ціннісні орієнтації в основному відповідають вимогам майбутньої професійної діяльності. Уміння діагностувати і планувати процес виховання професійно-етичної культури в основному сформовані; існує прагнення до самовдосконалення, але робота проводиться не завжди, як і рефлексія професійно-етичного досвіду. $€$ бажання створювати моральні візуальні образи, генерувати нові ідеї та методики створення композицій згідно етичному кодексу графічного дизайнера у процесі створення дипломних проектів, однак бракує досвіду, знань.

Для творчого (високого) рівня професійноетичної культури майбутнього графічного дизайнера характерний взаємозв' язок моральної свідомості та діяльності, що передбачає поінформованість про сутність етики, системність знань про професійно-етичну культуру та її фундамент, розуміння та чітке визначення змісту і сутності моральних понять, розмежування категорій “добра" i “зла". Етична кореляція під час виконання завдань завжди присутня, ціннісні орієнтації відповідають вимогам майбутньої професійної діяльності. Студенти, які знаходяться на даному рівні, можуть виявляти цінність, творчість, моральність, культуру, визнають важливість формування професійно-етичної культури, емоційно реагують на твори професійноетичного характеру. У майбутнього графічного дизайнера із високим рівнем сформовані вміння діагностувати і планувати процес аналізу, створення, правки візуального графічного продукту з урахуванням норм етики, приймати рішення, і нести за них відповідальність; існує стійке прагнення до самовдосконалення, що відбувається без примусу; вміння здійснювати рефлексію морально-етичного досвіду, співвіднесення особистісних інтересів 3 моральними та культурними потребами суспільства. Також ці студенти вміють генерувати нові ідеї та створювати моральні візуальні образи згідно етичному кодексу графічного дизайнера у процесі створення дипломних проектів.

Висновки 3 проведеного дослідження. Отже визначено: критерії формування професійноетичної культури графічних дизайнерів: інформаційно-знаннєвий (когнітивний компонент), мотиваційно-ціннісний (аксіологічний компонент), діяльнісний (діяльнісно-організаційний компонент), особистісно-креативний (особистісно-творчій компонент) критерії; рівні формування професійноетичної культури графічних дизайнерів: адаптивний (низький), репродуктивний (середній), творчий (високий). Напрямками подальших досліджень полягають у визначенні педагогічних умов формування професійно-етичної культури у майбутніх графічних дизайнерів.

\section{ЛІТЕРАТУРА}

1. Исаев И. Ф. Профессионально-педагогическая культура преподавателя : учеб. пособие для студ. высш. учеб. заведений. Москва, 2002. 208 с.

2. Каленський А. А. Розвиток професійнопедагогічної етики у майбутніх викладачів спеціальних дисциплін вищих навчальних закладів аграрної та природоохоронної галузей: монографія. Київ, 2016.391 с.

3. Каленський А. А., Мельник В. В. Критерії оцінювання підготовленості майбутніх геологів до використання геоінформаційних систем. Інформаційні технологї̈ і засоби навчання. 2018, Том 67, №5. С. 81-93.

4. Прохорчук П. С. Професійно-етична культура графічного дизайнера у науково-педагогічній літературі. Вісник Вінницького державного педагінчого ун-ту ім. М. Коцюбинського: “Сучасні інформаційні технології та інноваційні методики навчання в підготовці фахівців: методологія, теорія, досвід, проблеми". 2018. Вип. 50. С. 193-197.

5. Ситникова М. И. Формирование культуры профессионально-педагогической самореализации преподавателя высшей школы: автор. дис. ... д-ра пед. наук : 13.00.08. Белгород, $2008.42 \mathrm{c}$.

6. Український педагогічний словник / Семен Гончаренко; [гол. ред. С. Головко]. Київ, 1997. С. 373, 182 с. 


\section{АКТУАЛЬНІ ПРОБЛЕМИНАЦІОНАЛЬНО-ПАТРІОТИЧНОГО ВИХОВАННЯ В ЗАКЛАДАХ ВИЩОЇ ОСВІТИ}

\section{REFERENCES}

1. Isaev, Y. F. (2002). Professyonalno-pedahohycheskaia kultura prepodavatelia : ucheb. posobye dlia stud. vussh. ucheb. zavedenyi [Professional and pedagogical culture of the teacher: studies. allowance for students of higher educational establishments]. Akademyia, 208 p. [in Russian].

2. Kalenskyi, A. A.(2016). Rozvytok profesiinopedahohichnoi etyky u maibutnikh vykladachiv spetsialnykh dystsyplin vyshchykh navchalnykh zakladiv ahrarnoi ta pryrodookhoronnoi haluzei [The system of development of vocational and pedagogical ethics for future teachers of special disciplines of higher educational institutions of agrarian and environmental branches]. Kyiv, 391 p. [in Ukrainian].

3. Kalenskyi, A. A. \& Melnyk, V. V. (2018). Kryterii otsiniuvannia pidhotovlenosti maibutnikh Heolohiv do vykorystannia heoinformatsiinykh system [Criteria for assessing the preparedness of future geologists for the use of geographic information systems]. Kyiv. p. 67, no.5.pp. 81-93. [in Ukrainian].

4. Prokhorchuk, P. S. (2018). Profesiino-etychna kultura hrafichnoho dyzainera u naukovo-pedahohichnii literature [Professional and ethical culture of graphic designer in scientific and educational literature]. Herald of Vinnitsa State Pedagogical University. un-th them M. Kotsyubinsky: "Modern Information Technologies and Innovative Methods of Training in the Training of Specialists: Methodology, Theory, Experience, Problems". No. 50, pp. 193-197. [in Ukrainian].

5. Sytnykova, M. Y. (2008). Formyrovanye kultury professyonalno-pedahohycheskoi samorealyzatsyy prepodavatelia vysshei shkoly [Formation of a culture of professional and pedagogical self-realization of a teacher of higher education]. Belgorod,42 p. [in Russian].

6. Goncharenko, S. (1997). Ukrayinskiyj pedagogichnyji slovnyk [Ukrainian Pedagogical Dictionary]. (Ed.).S. Golovko. Kyiv, p.373; 182 p. [in Ukrainian].

Стаття надійшла до редакції 13.03.2019

УДК: 378.015.31:316.42-057,875

DOI:

Уляна Ткаченко, аспірант Хмельницької гуманітарно-педагогічної академії

\section{АКТУАЛЬНІ ПРОБЛЕМИ НАЦІОНАЛЬНО-ПАТРІОТИЧНОГО ВИХОВАННЯ В ЗАКЛАДАХ ВИЩОЇ ОСВІТИ}

У статті розкрито актуальні проблеми національно-патріотичного виховання в закладах вищоїосвіти. Звернено увагу на сутність патріотизму, його різновиди, зокрема етнічний, територіальний, держсавний. Визначено особливості начіонального виховання студентів, спрямоване на культурно-історичний досвід рідного народу, його традииї, звичаї, обряди. Акиентовано на формування ціннісного ставлення особистості до Батьківщини, держави, нації, готовності до захисту начіональних інтересів, незалежності Украӥни. Виокремлено завдання та принципи національно-патріотичного виховання, зокрема принципи начіональної спрямованості, самоактивності та самореалізації полікультурності, історичної і сочіальної пам'яті та ін. Зазначено форми патріотичного виховання у закладах вищзої освіти. Це інформаційно-масові, діяльнісно-практичні, індивідуальні, наочні та ін. Запропоновано окремі виховні заходи, проведені в Хмельницькій гуманітарно-педагогічній академї: інформаційномасові (дискусії, диспути, конферениії, “філософський стіл”, “відкрита кафедра”, інтелектуальні аукиіони, ринги, вікторини, вечори, подорожі до джерел рідної культури, історії держави і права, “жива газета”, створення книг, альманахів); діяльнісно-практичні (творчі групи, осередки, екскурсї, свята, театр-експромт, ігридраматизаиії, огляди-конкурси, олімпіади); інтегративні (клуби, фестивалі, асамблеї, гуртки); діалогічні (бесіда, міжрольове спілкування); індивідуальні (доручення, творчі завдання, звіти, індивідуальна робота тощо); наочні (музеї, кімнати, зали, галереї, виставки студентської творчості, книжскові виставки, тематичні стенди тощо).

Ключові слова: начіонально-патріотичне виховання; заклади вищої освіти; завдання та принципи національно-патріотичного виховання; форми національно-патріотичного виховання.

תim. 6.

Ulyana Tkachenko, Pastgraduate Student of Khmelnytskiy Humanitarian Pedagogical Academy

\section{TOPICAL PROBLEMS OF NATIONAL-PATRIOTIC EDUCATION IN THE INSTITUTIONS OF HIGHER EDUCATION}

The article deals with the topical problems of national-patriotic education in institutions of higher education. The attention is paid to the essence of patriotism, its varieties, in particular ethnic, territorial, and state. The peculiarities of the national education of students, aimed at the cultural-historical experience of the native people, their traditions, customs, rituals have been determined. The emphasis is on the formation of the person's value attitude towards the Motherland, the state, the nation, readiness to protect national interests, and the independence of Ukraine. The tasks and principles of national-patriotic education, in particular the principles of national orientation, self-actualization and self-realization of multiculturalism, historical and social memory, etc. have been singled out. The forms of patriotic education in higher education institutions have been indicated. 